\title{
THE EFFECTIVENESS OF THE TOURISM AWARENESS EDUCATION MODEL FOR COMMUNITY-BASED TOURISM OBJECT MANAGERS IN AGAM DISTRICT, SUMATERA BARAT, INDONESIA
}

\author{
Rahmi Novalita', Ahyuni'2, Mona Adria Wirda ${ }^{3}$ Afrital Rezki ${ }^{4}$ \\ 1Pendidikan Geografi, Fakultas Keguruan dan Ilmu Pendidikan, Universitas Almuslim \\ Jl. Almuslim Matangglumpangdua, Peusangan, Bireuen, Aceh, 24261, Indonesia \\ 2Program Studi Geografi, Fakultas Ilmu Sosial, Universitas Negeri Padang \\ J1. Prof. Dr. Hamka, Air Tawar, Padang, Sumatera Barat, 25173, Indonesia \\ ${ }^{3}$ Digital Learning and Education, College of Liberal Arts and Social Sciences, \\ National Taiwan University of Science and Technology \\ No. 43, Keelung Rd., Sec. 4, Da'an Dist., Taipei City 106335, Taiwan (R.O.C) \\ 4Program Studi Pendidikan Geografi, STKIP PGRI Sumatera Barat \\ Jl. Gunung Pangilum, Padang Utara, Kota Padang, Sumatera Barat, 25111, Indonesia \\ e-mail : monaadria@unimed.ac.id
}

Received: 22 March 2021, Repaired: 23 June 2021, Approved: 24 June 2021

\begin{abstract}
Abstrak
Penelitian ini bertujuan untuk mendeskripsikan desain model pendidikan kesadaran wisata berbasis masyarakat dan keefektifan model pendidikan kesadaran wisata. Penelitian ini termasuk dalam jenis penelitian Research and Development (RED) dengan menggunakan model ADDIE. Populasinya adalah pengelola objek wisata berbasis masyarakat yang berjumlah 20 orang dengan teknik incidental sampling yang kemudian dibagi menjadi 2 kelompok. Hasil penelitian menunjukkan bahwa: 1) desain model pendidikan kesadaran wisata berbasis masyarakat terdiri dari; calon peserta dan seleksi calon peserta dengan tahapan persiapan meliputi; a) tujuan, materi, strategi, prosedur, media, bahan ajar, evaluasi, b) sosialisasi pengenalan program, c) pelaksanaan program, dan d) pendampingan; 2) keefektifan model pendidikan kesadaran wisata berbasis masyarakat dilihat dari hasil uji peserta yang menunjukkan adanya perbedaan hasil sebelum dan sesudah pendidikan, dimana setelah pendidikan diperoleh nilai rata-rata yang lebih tinggi, dengan standar deviasi yang lebih kecil . Meski dibagi menjadi 2 kelompok, hasil pendidikan menunjukkan bahwa tidak ada perbedaan yang signifikan antara nilai post-test pada kelompok 1 dan kelompok 2. Hal ini membuktikan bahwa pendidikan telah efektif dalam memberikan kesadaran bagi pengelola objek berbasis komunitas.
\end{abstract}

Kata Kunci: Efektivitas, Model Pendidikan Kesadaran Wisata, Pengelola Objek Wisata Berbasis Masyarakat, Model ADDIE

\begin{abstract}
This research aims to describe the design of the community-based tourism awareness education model and the effectiveness of the tourism awareness education model. This research is included in the Research and Development (RED) type of research utilizing the ADDIE model. The population was the manager of a community-based tourist attraction, amounting to 20 people with the incidental sampling technique which was then divided into 2 groups. The results showed that: 1) the design of a community-based tourism awareness education model consisted of; candidate participants and selection of
\end{abstract}


potential participants with the preparation stage including; a) objectives, materials, strategies, procedures, media, teaching materials, evaluation, $b$ ) socialization of program introduction, c) program implementation, and d) mentoring; 2) the effectiveness of the community-based tourism awareness education model was seen from the test results of participants which showed that there were differences in the results before and after education, where after education a higher average value was obtained, with a smaller standard deviation. Although divided into 2 groups, the educational results showed that there was no significant difference between the post-test scores in group 1 and group 2. This proves that education has been effective in providing awareness for communitybased object managers.

Keywords: Effectiveness, Tourism Awareness Education Model, Community-based Tourism Object Manager, ADDIE Model

\section{INTRODUCTION}

Various regions in Indonesia have great tourism potential, which can be essential to optimize all of its potentials for implement the value of the prosperity and welfare of the community through Law No. 10 of 2009 concerning tourism. This law implies that all natural resources including natural conditions, flora and fauna, ancient relics, historical relics, arts, and culture that belong to the Indonesian Nation are gifts from God which can be used as resources for sustainable tourism development to develop prosperity and welfare of the people.

The West Sumatra Province, especially Kabupaten Agam, is one of the mainstay areas in the tourism sector, but in contrast, the community lacks the ability and knowledge to develop this potential. This circumstance requires the right solutions and strategies toward developing regional tourism potential. The tourism potential in the region is enormous and has diversity by prioritizing beauty and uniqueness. Developing tourism requires participation from all parties, including: a) government, b) private sector, and c) community. The government acts as a facilitator in tourism development, the private sector plays a role as the main actor and figure (spearhead) in tourism development, while the community plays an active role as an active actor and participates in the development of tourism in their respective regions (Kementerian Pariwisata dan Kebudayaan, 2016).

The tourism development process involves the community as a catalyst in economic development and the sustainability of the tourism industry. The community awareness-raising, as well as increasing the participation in tourism activities and environmental sustainability, can be seen in the development of the Nyarai Tourism Object in the Pariaman Regency. Learning the involvement of the people of Nyarai Waterfall, rising from individuals, Pokdarwis (Tourism Awareness Group) and LPHN (Nagari Forest Management Institute). These tourism objects offer a significant contribution both in terms of community income and awareness of the importance of maintaining shared capital. (Febriani, Melya, 2018). Furthermore, a study conducted in the Philippines shows the need for a new strategy to engage and make people aware of the importance of protecting the sea with fishing communities using remote fishing communities. The strategy previously carried out in the form of a CBT (community-based tourism) strategy has various shortcomings, so it is proposed to increase public awareness using the Social Entrepreneurship Tourism 
Model or a social entrepreneurship-based tourism model (Brooke A, Porter., 2017).

The involvement of local communities in the tourism business is influenced by two main factors, namely income and family drive, in addition to the existence of beliefs, interests, and opportunities (Hanim, Norlida 2013). Based on observations, there are several problems with tourism awareness of the tourism object community in Tirta Sari, Tilatang Kamang District, Kabupaten Agam. First, there is constant neglect of the process of community participation in communitybased tourism object management which includes planning, implementation, and supervision. Second, the limited knowledge of community-based tourism object managers in creating elements of attraction which include; cleanliness, order, comfort, security, beauty, coolness, and memories. Third, the tendency of people as managers of tourism objects to have limited knowledge, insight in solving tourism problems, studying approximately, and insights in developing tourist objects. Fourth, people have different levels of education so they have different knowledge. Lastly, limited training for community-based tourism object managers.

To overcome the above problems, a tourism awareness education model is needed to help stakeholders, especially the community as managers of tourism objects by providing stimulus, awareness, and motivation in developing tourism education through the tourism awareness education module (Novalita R, 2018, 2019). The novelty in the research is the design of a tourism-aware education model and a tourism-aware education module for tourism object managers. The module is a guideline or activity steps in an effort to improve tourism awareness education. While the learning module serves to improve the knowledge, attitudes, and skills of community-based tourism object managers in practicing learning outcomes in tourism object development.

The Tourism Awareness Education Model is an independent learning approach that aims to ensure that community-based tourism object managers have the capacity and competencies by studying the materials from the module of community-based tourism object managers according to their potential and needs. Learning using modules means learning that focuses on the independent role of tourism object managers in increasing interest in collaborative learning. Interest in collaborative learning has become the latest trend in education towards active learning, where students are actively engaged in building their knowledge through discovery, discussion, and expert guidance. Collaborative learning is a learning approach that leads to constructivism theory (Vygotsky, 1978), and has been used as a learning strategy that is practiced around the world for many years (Ansyar, 2015). Many research results explain the advantages of collaborative learning among others, increasing academic performance, promoting soft skills development (namely, communication, collaboration, problem-solving, and critical thinking skills), and increasing satisfaction in the learning experience (Kabilan, et.al, 2011; Lee \& Lim, 2012; Nurbiha et.al, 2012; Zhu, 2012, Novalita, 2018, 2019).

The module learning process is the process of delivering information to community-based tourism object managers. Particular interests are: (1) increasing the effectiveness of learning due to conditions, socio-economic, geographic, and social situations; (2) there are learning opportunities according to the needs of community-based tourism object managers; (3) knowing the competence attainment of community-based tourism object managers; (4) assisting community-based tourism object managers in understanding 


\section{gẹafi}

competencies that have not been achieved so that facilitators can assist in remediation RESEARCH METHOD

The type of research is Research and Development (R\&D) utilizing the ADDIE model (Dick, Carey \& Carey 2001). This model is widely used in the field of guiding model development (Morrison, 2010; Nadiyah and Faaizah, 2015). the procedures include 1) Analysis, 2) Design, 3) Development, 4) Implementation, and 5) Evaluation. The research subject is 20 managers of the community-based tourism object of the Lake Tarusan Kamang and the Tirta Sari Sonsang Tourism Object, Tarusan Kamang, Kabupaten Agam. Analysis of research data consists of qualitative and quantitative analysis through validation (Muliyardi, 2006), practicality testing (Arikunto, 2006; Purwanto, 2009; Riduwan, 2008), and testing the effectiveness of learning modules that have been developed
Available at http://jurnal.unimed.ac.id/2012/index.php/geo e-ISSN: 2549-7057 | p-ISSN: 2085-8167

(Ministry of National Education, 2008: 7-8).

(Arikunto, 2006; Purwanto, 2009; Abidin, 2012; Sugiono, 2012).

\section{RESULTS AND DISCUSSION}

\section{A. Tourism Awareness Education Model}

The tourism awareness education model is one of the model designs in solving solutions to research problems. The model design can be seen in figure 1 . The design of the tourism awareness education model can be explained as follows:

\section{Prospective Participants}

Prospective participants are people who are involved as members of the tourism awareness group. Prospective participants are based on findings in both Lake Tarusan Kamang and the Tirta Sari Sonsang Tourism Object, Kabupaten Agam, are still low in awareness of tourism.

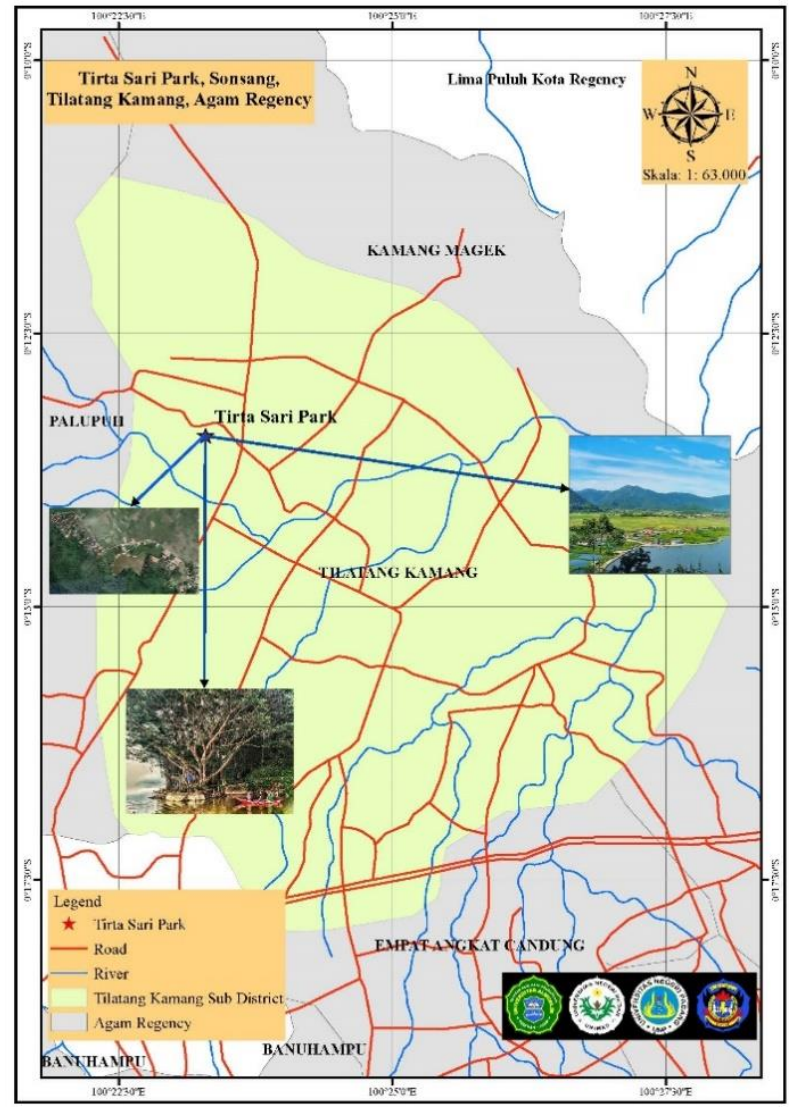

Figure 1. Tirta Sari Park, Somsang, Tilatang Kamang, Kabupaten Agam 


\section{Participant Selection}

Selection of Participants managing tourism objects in this program is community-based natural tourism object managers involved in tourism awareness groups totaling 20 people. the guideline of the Community-based Tourism
Awareness Education Program designed as a module, which includes:

a. Preparation

The steps taken are compiling tools, media, learning resources, and places of learning.

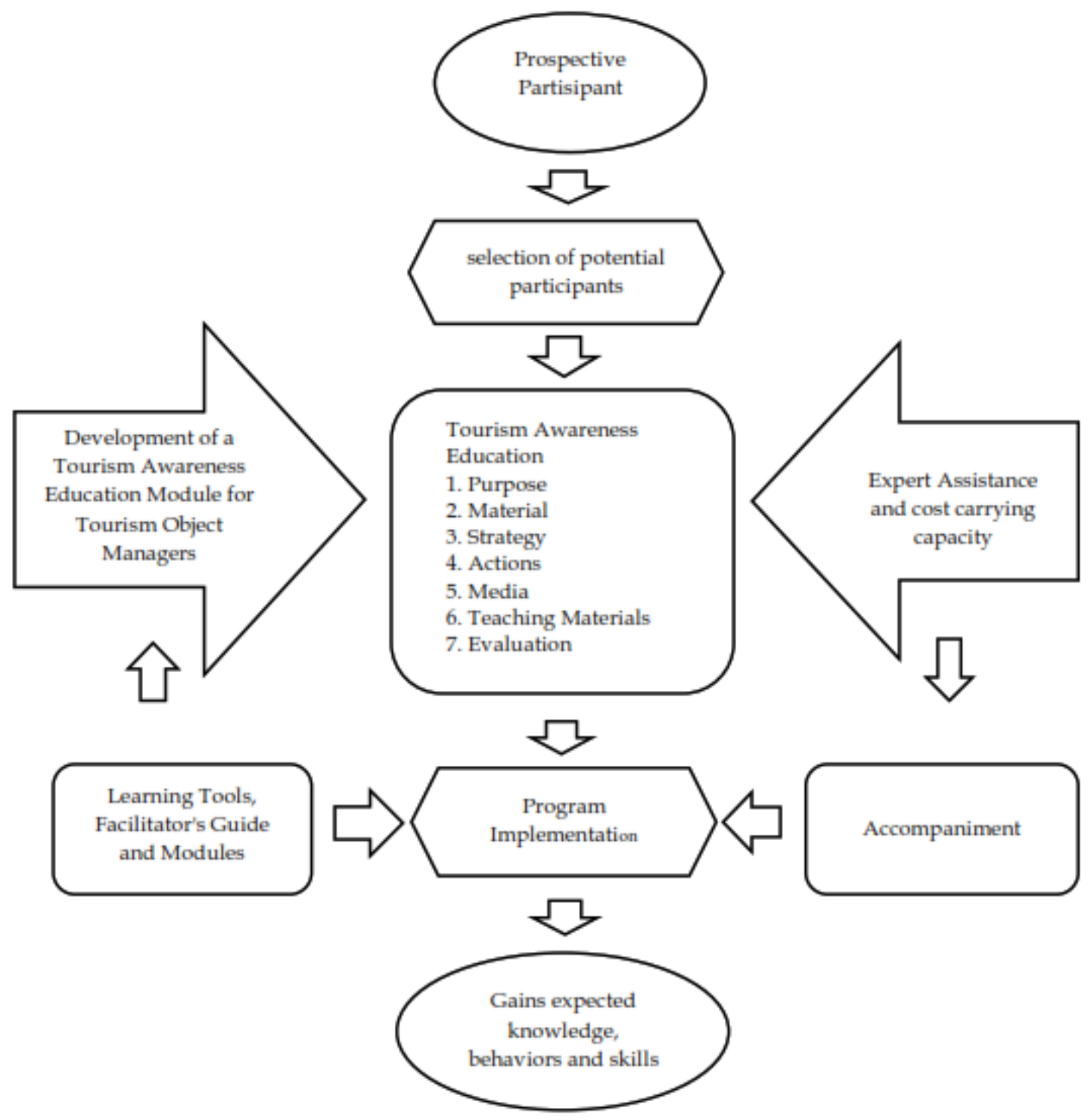

Figure 2. The Tourism Awareness Education Model Design

1) Learning objectives.

Activities carried out aim to provide training and assistance so that; a) community-based tourism object managers have the knowledge, attitudes, and skills in managing tourist objects, b) increase the participation of community-based 
tourism object managers in managing tourist objects to increase income.

2) Material

The training material includes a) the concept of tourism awareness and "sapta pesona pariwisata", b) tourism awareness group organization, c) establish tourism awareness group structure, d) guidance and development of tourism awareness group.

3) Strategy

The learning strategy applied in learning is discovery learning.

4) Actions

The steps for tourism awareness education activities include three activities; a) introduction, b) presentation, c) closing.

5) Media

The media needed in tourism awareness learning activities are laptops, LCD.

6) Teaching Materials

The teaching materials used in learning are tourism awareness education modules.

7) Assessment

The assessment was carried out to determine the level of advancement of the community-based tourism object manager after studying the module.
The assessment is carried out in the form of a formative and summative test.

b. Program Introduction Socialization Program socialization is carried out to the people involved as managers of tourist objects through FGD, its involving, prospective participants, village officials, tourism agencies.

c. Program Implementation

The tourism awareness education module development program is carried out through learning activities. Learning activities are carried out at the location of the Tirta Sari Kanagarian Sonsang tourist attraction, Kabupaten Agam. This learning activity is carried out to motivate community-based tourism object managers.

d. Accompaniment

Mentoring is carried out during the learning process, both before and after using the module.

\section{B. The effectiveness of The Tourism Awareness Education Model}

The assessment of learning outcomes for the Tourism Consciousness Education Model was carried out through tests (Table 1).

Table 1. Descriptive Statistics

\begin{tabular}{lcccc}
\hline & N & Mean & Std. Deviation & Variance \\
\hline Pre_Test.K1 & 10 & 66.5000 & 25.34499 & 642.368 \\
Post_Test.K1 & 10 & 84.0000 & 10.21981 & 104.444 \\
Pre_Test.K2 & 10 & 55.5000 & 19.64264 & 385.833 \\
Post_Test.K2 & 10 & 88.0000 & 11.10555 & 123.333 \\
Valid N (listwise) & 10 & & & \\
\hline
\end{tabular}

Source: Research Result, 2020

Based on the descriptive statistical results, it can be concluded that there are differences in the mean, standard deviation, and variance. Where the mean value of Pre_Test.K1 is 66.5, standard deviation is
25.3, variance value is 642.3. Post_test. K1 mean value is 84 , standard deviation is 10 , 2 , and variance value is 104.4. Meanwhile, the mean value of Pre_Test.K2 is 55.5, the standard deviation is 19.64, and variance value is 385.8. The average post_test.K2 
score is 88 , standard deviation is 11,1 , variance value is 123.3 .

Table 2. Pre-Test and Post-Test

\begin{tabular}{llllll}
\hline \multirow{2}{*}{ Groups } & \multicolumn{3}{c}{ Score } & Mean of Gain \\
\cline { 2 - 5 } & \multicolumn{3}{c}{ Pre-Test } & \multicolumn{1}{c}{ Post-Test } & \\
\cline { 2 - 5 } Group 1 & $\bar{x}$ & $: 66,50$ & $\bar{x}$ & $: 84,00$ & \multirow{2}{*}{17,10} \\
& SD & $: 25,34$ & SD & $: 10,22$ & \\
& Var & $: 642,368$ & Var & $: 104,444$ & \\
& $\bar{x}$ & $: 55,50$ & $\bar{x}$ & $: 88,00$ & 32,50 \\
Group 2 & SD & $: 19,64$ & SD & $: 11,11$ & \\
& Var & $: 385,833$ & Var & $: 123,333$ & \\
& & \multicolumn{3}{c}{} \\
\hline
\end{tabular}

Source: Research Result, 2020

The results of the pretest and posttest tests of the two groups can be concluded that there are differences in each score and the average gain score. Group 1 had a pre-test mean of 66,50 , a standard deviation of 25.34, a variance of 642.3 , an average post-test score of 84.0 , a standard deviation of 10.22, a variance of 104.4, an average gain score. 17.10. Meanwhile, group 2 had a pre-test average value of 55.50, a standard deviation of 19.54, a variance of 385.8 , an average post-test score of 88.0 , a standard deviation of 11.11, a variance of 123 and an average gain score. 32.50.

Table 3. Tests of Normality

\begin{tabular}{lcccccc}
\hline & \multicolumn{3}{c}{ Kolmogorov-Smirnov ${ }^{a}$} & \multicolumn{3}{c}{ Shapiro-Wilk } \\
\cline { 2 - 6 } & Statistic & Df & Sig. & Statistic & Df & Sig. \\
\cline { 2 - 6 } Pre_Test.K1 & .157 & 10 & $.200^{*}$ & .901 & 10 & .226 \\
Post_Test.K1 & .139 & 10 & $.200^{*}$ & .950 & 10 & .665 \\
Pre_Test.K2 & .191 & 10 & $.200^{*}$ & .864 & 10 & .086 \\
Post_Test.K2 & .194 & 10 & $.200^{*}$ & .861 & 10 & .078 \\
\hline
\end{tabular}

* This is a lower bound of the true significance.

a. Lilliefors Significance Correction

Source: Research Result, 2020

The results of the normality test show the significance value of each data group in the Kolmogorov-Smirnov test of 0.200. Meanwhile, the Shapiro - Wilk test obtained each class of $0.226,0.665,0.086$, and 0.078. Of the two types of tests, the significance value is greater than the alpha of the study $(0,05)$. This means that the pretest and post-test data groups were normally distributed.

Table 4. Test of Homogeneity of Variance

\begin{tabular}{llcccc}
\hline & & $\begin{array}{c}\text { Levene } \\
\text { Statistic }\end{array}$ & df1 & df2 & Sig. \\
\hline \multirow{2}{*}{ Value } & Based on Mean & 1.922 & 3 & 36 & .143 \\
& Based on Median & 1.168 & 3 & 36 & .335 \\
& Based on Median and with adjusted df & 1.168 & 3 & 22.145 & .344 \\
& Based on trimmed mean & 1.789 & 3 & 36 & .167 \\
\hline
\end{tabular}

Source: Research Result, 2020. 
The homogeneity of the variance using the Levene test obtained a significance value of 0.143 while the alpha value of the study was 0.05 . Thus, the significance value was greater than alpha
(0.143> 0.05) which could be interpreted that the pretest and posttest values for the two groups had the same variance (homogeneous) at a significant level of 0,05 .

\section{Discrimination Test of Pre-Test dan Post-Test K2}

Table 8. Paired Samples Statistics

\begin{tabular}{llcccc}
\hline & & Mean & N & Std. Deviation & Std. Error Mean \\
\hline \multirow{2}{*}{ Pair 1 } & Pre_Test.K2 & 55.5000 & 10 & 19.64264 & 6.21155 \\
& Post_Test.K2 & 88.0000 & 10 & 11.10555 & 3.51188 \\
\hline
\end{tabular}

Source: Research Result, 2020.

Table 9. Paired Samples Correlations

\begin{tabular}{llccc}
\hline & & N & Correlation & Sig. \\
\hline Pair 1 & $\begin{array}{l}\text { Pre_Test.K2 \& } \\
\text { Post_Test.K2 }\end{array}$ & 10 & .005 & .989 \\
\hline
\end{tabular}

Source: Research Result, 2020

Table 10. Paired Samples Test

\begin{tabular}{|c|c|c|c|c|c|c|c|c|c|}
\hline & & \multicolumn{5}{|c|}{ Paired Differences } & \multirow{3}{*}{$\mathrm{T}$} & \multirow{3}{*}{$\mathrm{df}$} & \multirow{3}{*}{$\begin{array}{l}\text { Sig. (2- } \\
\text { tailed) }\end{array}$} \\
\hline & & \multirow[t]{2}{*}{ Mean } & \multirow[t]{2}{*}{ SD } & \multirow[t]{2}{*}{ SE Mean } & \multicolumn{2}{|c|}{$\begin{array}{l}\text { 95\% Confidence } \\
\text { Interval of the } \\
\text { Difference }\end{array}$} & & & \\
\hline & & & & & Lower & Upper & & & \\
\hline Pair 1 & $\begin{array}{l}\text { Pre_Test.K2 } \\
- \\
\text { Post_Test.K } \\
2\end{array}$ & 32.50000 & $\begin{array}{r}22.5154 \\
3\end{array}$ & 7.12000 & -48.60657 & -16.39343 & 4.565 & 9 & .001 \\
\hline
\end{tabular}

Source: Research Result, 2020.

\section{Interpretation:}

a) On the output Paired Sample Correlation: Sig. > from alpha or 0.989> 0.05 , then the data does not have a significant relationship.

b) On the output Paired Sample Test: The value of $t$ hit> $t$ tab (4.565> 2.262) then the data has different means. (-t1 / 2a> $\mathrm{t}>\mathrm{t} 1 / 2 \mathrm{a}=$ Accept Hi)

c) Sig. Value (two tails) < then alpha (0.001 $<0.05)$, then there is a significant difference

Table 11. Group Statistics

\begin{tabular}{cccccc}
\hline Kode & & $\mathrm{N}$ & Mean & $\begin{array}{c}\text { Std. } \\
\text { Deviation }\end{array}$ & Std. Error Mean \\
\hline \multirow{2}{*}{ Value } & 1.00 & 10 & 84.0000 & 10.21981 & 3.23179 \\
& 2.00 & 10 & 88.0000 & 11.10555 & 3.51188 \\
\hline
\end{tabular}


Source: Research Result, 2020.

\begin{tabular}{|c|c|c|c|c|c|c|c|c|c|}
\hline & \multicolumn{2}{|c|}{$\begin{array}{c}\text { Levine's Test } \\
\text { for Equality of } \\
\text { Variances }\end{array}$} & \multicolumn{7}{|c|}{ t-test for Equality of Means } \\
\hline & \multirow[t]{2}{*}{$\mathrm{F}$} & \multirow[t]{2}{*}{ Sig. } & \multirow[t]{2}{*}{$\mathrm{t}$} & \multirow[t]{2}{*}{$\mathrm{df}$} & \multirow{2}{*}{$\begin{array}{l}\text { Sig. (2- } \\
\text { tailed) }\end{array}$} & \multirow{2}{*}{$\begin{array}{c}\text { Mean } \\
\text { diff. }\end{array}$} & \multirow[t]{2}{*}{ SE diff. } & \multicolumn{2}{|c|}{$\begin{array}{l}95 \% \text { Confidence } \\
\text { interval of the diff. }\end{array}$} \\
\hline & & & & & & & & Lower & Upper \\
\hline $\begin{array}{l}\text { Value Equal variances } \\
\text { assumed }\end{array}$ & .005 & -.942 & -.838 & 18 & .413 & -4.00 & 4.77261 & -14.02688 & 6.02688 \\
\hline $\begin{array}{l}\text { Equal variance not } \\
\text { assumed }\end{array}$ & & & -.838 & 17.877 & .413 & -4.00 & 4.77261 & -14.03182 & 6.03182 \\
\hline
\end{tabular}

Source: Research Result, 2020

Interpretation:

a) Value of Sig. In the Levene test $>$ from alpha $(0.942>0.05)$, the two data groups have the same variance

b) The value of $t$ hit $<\mathrm{tab}(-0.838<2.262)$ then the data has different means

c) Value of Sig. (two tails) > alpha (0.413> $0.05)$, then the difference is not significant.

The community-based tourism awareness education model is a model framework that outlines the steps in conducting research. The purpose of developing the model is to solve problems in the field based on the results of needs analysis, student analysis, and environmental analysis.

Analysis of development needs through learning for the community, especially managers of community-based tourist objects to develop their potential as managers of tourist objects in order to increase knowledge and create adequate conditions for tourism development in the regions in realizing the charm of tourist objects (Novalita, R 2018,2019). Analysis of students in terms of the characteristics of students have different understandings. So it is necessary to develop teaching materials in order to help managers of communitybased tourism objects in increasing knowledge and skills. Environmental analysis is necessary for the success of tourism development by involving community participation and support, especially community-based tourism object managers in encouraging the development of environmentally friendly tourism objects. (Novalita, 2019)

Based on the results that have been presented, they are summarized in a theoretical basis for developing a wistaconscious education model in learning for tourism object managers as has been revealed by cognitive-field theories which view learners in relation to the environment (Ornstein \& Hunkin, 1988: 84). This is a principle that learning is a restructuring and integration of the entire field atmosphere that produces understanding. Structural functionalism theory describes something that is urgent and very useful in events concerning the analysis of social problems and has a great influence. In addition, according to Parson there are four important functions that are absolutely necessary for all social systems, namely Adaptation (A), Achievement of goals or Goal attainment. (G), Integration (I), and Latency (L) or with the abbreviation AGIL (Narwoko, D. \& Suyanto B. (2002). The use of some of these theories has created a tourism awareness education model including: 1) potential participants, 2) selection of prospective participants, 3) the preparation stage includes a) objectives, materials, strategies, steps, media, teaching materials, evaluation, b) socialization of 
program introduction, c) program The development of a tourism awareness education model is one of the problem-solving strategies in developing sustainable tourism. Through the design of a tourism awareness education model based on the results of the analysis of the needs of field observations and interviews with several Tourism Offices regarding environmental problems around tourist objects, the availability of community education activities, especially for community-based tourism object managers, as well as tourism awareness analysis for community-based tourism object managers. The application of the tourism awareness education model has an influence on student learning outcomes in terms of test results which are classified as very effective. The effectiveness of the Tourism Conscious Education Model. A teaching material is said to be effective if it has a good effect or influence on the achievement of learning objectives. The effectiveness of the learning program is characterized by the following characteristics: a) succeed in delivering students to achieve the instructional goals that have been set, $b$ ) provide an attractive experience, c) involve students actively to support the achievement of instructional goals, c) have the means that support the learning process (Ansyar, 2015).

The results of the test on the effectiveness of the tourism awareness education model show that the treatment of the two experimental groups has a implementation, d) mentoring. consistent effect. The value of $t$ hit $<t$ tab ($0.838<2.262$, Sig. Value (two tails) $>$ of alpha $(0.413>0,05)$, then the difference is not significant. This proves that tourism awareness education provides awareness for community-based object managers. tourism is a community participation in the form of community participation which illustrates the encouragement of the community to create conditions that are conducive to the development of tourism in an area. There are several roles of public awareness among others. (a) Community as a good host and has the responsibility of visiting guests or tourists so that they are able to create a conducive environment and atmosphere as stated in the slogan Sapta Pesona. (b) there are rights and needs that are recognized by the community to become tourist actors in traveling to a tourist destination, as a form of basic need for recreation and especially in men familiar and loving the homeland (Ministry of Tourism and Culture, 2012: 11). In essence, tourism development involves the roles of all existing and related stakeholders. The components involved in stakeholders include: 1) the government, 2) the private sector, and 3) the community, with their various duties and functions. These stakeholders cannot stand alone, of course they must work together and step together to achieve and realize agreed development goals and objectives.

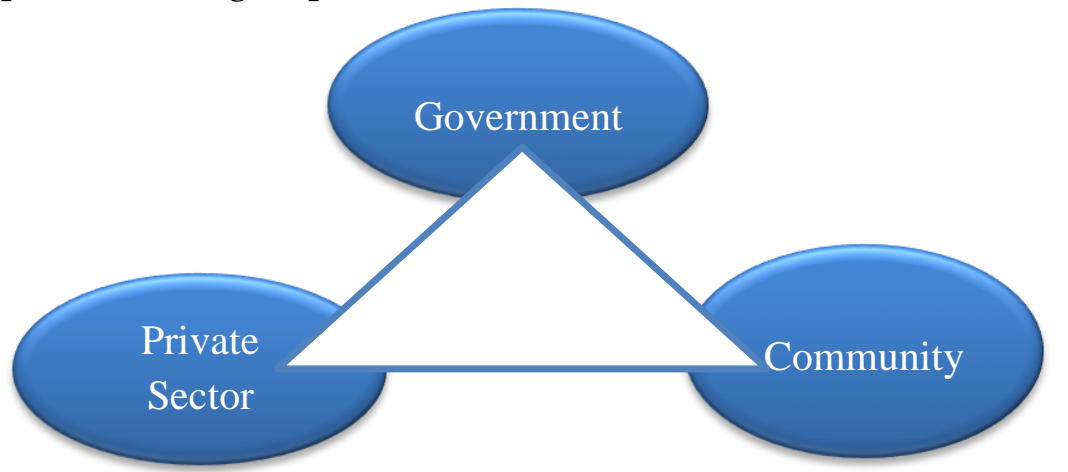

Figure 3. Stakeholders in Tourism Development ((Murplay, 1990) 
Based on the description of the roles and functions of each stakeholder, it is explained as follows: a) the government in accordance with its duties and authorities carries out its role and function as a facilitator in making regulations (regulators) in tourism development activities, b) the private sector (business actors / tourism industry ) with the resources, capital and networks they have, carry out their roles and functions as a developer and implementer of tourism development activities, c) the community with its resources, whether in the form of customs, traditions and culture as well as its capacity, play a role as host, however also at the same time have the opportunity to be an actor in tourism development according to their capabilities (Ministry of Tourism and Culture, 2012).

\section{CONCLUSION}

The conclusions of the research results of the tourism awareness education model are as follows.

1) The design of the tourism awareness education model includes 1) prospective participants, 2) selection of potential participants, 3) the preparation stage includes a) objectives, materials, strategies, steps, media, teaching materials, evaluation, b) socialization of program introduction, c) program implementation, d) mentoring.

2) The effectiveness of the communitybased tourism awareness education model seen from the test results of the training participants obtained the $t$ hit value $<\mathrm{t}$ tab $(-0.838<2.262$, the Sig. Value (two tails) $>$ of alpha $(0.413>0,05)$ was classified as insignificant so that the treatment in the two experimental groups gave a consistent effect.

\section{REFERENCE LIST}

Ansyar, M. (2015). Kurikulum Hakikat, Fondasi, Desain dan Pengembangan (Cetakan 1). Jakarta: PT. Kencana.

Darmawan, R. (2008). Skala Pengukuran Variabel-Variabel Penelitian. Bandung; Alfabeta

Dick, W. \& Carey, L. (2001). The Systematic Design of Instruction. United States: Addison Wesley Educational Publishers Inc.

Direktorat Tenaga Kependidikan Direktorat Jenderan Peningkatan Mutu Pendidikan Dan Tenaga Kependidikan Departemen Pendidikan Nasional. (2008). "Penulisan modul". Jakarta

Febriani, M. F. (2018). Keterlibatan Masyarakat dalam Pengembangan Objek Wisata Di Kecamatan Lubuk Alung dan Batang Anai Kabupaten Padang Pariaman (Studi Kasus: Air Terjun Nyarai, Tapian Puti dan Rumah Pohon Manang). Jurnal Buana, 2(1), 205-205.

Kabilan, M. K., Adlina, W. F. W., \& Embi, M. A. (2011). Online collaboration of English language teachers for meaningful professional development experiences. English Teaching: Practice and Critique, 10(4), 94-115.

Kementrian Pariwisata dan Kebudayaan. (2016). Pedoman Kelompok Sadar Wisata. Jakarta. Kementerian Pariwisata.

Lee, H.-J. \& Lim, C. (2012). Peer Evaluation in Blended Team Project-Based Learning; What Do Students Find Important? Educational Technology \& Society, 15(4), 214-224Morrison, G. R. (2010). Designing Effective Instruction (6th Edition.). John Wiley \& Sons.

Nadiyah, R. S., \& Faaizah, S. (2015). The development of online project based collaborative learning using ADDIE model. Procedia-Social and Behavioral Sciences, 195, 1803-1812.

Narwoko, D., \& Suyanto, B. (2007). Sosiologi Teks Pengantar Dan Terapan: 
Jakarta. Kencana, Prenada Media Group.

Novalita R. (2018). Object management Response to Practicality Concicious Tourisma Educational Module. Prosiding Seminar Nasional Biologi Edukasi. ISSN 2579-7766.

Novalita, R. (2019). Praktikalitas Modul Pendidikan Sadar Wisata Bagi Pengelola Objek Wisata Berbasis Masyarakat Di Kabupaten Agam Sumatera Barat. Jurnal Spasial, 6, 62-67.

Novalita, R., Barlian, E., Muchtar, B., \& Syah, N. (2018). Design of a tourism awareness education module for tourism attraction managers in Agam District, West Sumatra. African Journal Hospitality, Tourism and leasure, 3.

Ornstein, A. C., \& Hunkins, P. P. (1988). Competency In the Work World. Prentice Hal of India.

Porter, B. A., Orams, M. B., \& Lück, M. (2018). Sustainable entrepreneurship tourism: An alternative development approach for remote coastal communities where awareness of tourism is low. Tourism Planning $\mathcal{E}$ Development, 15(2), 149-165.

Puwanto, M. N. (2009). Prinsip-Prinsip dan Teknik Evaluasi pengajaran. Bandung. Remaja Rosdakarya.

RI (Republik Indonesia). (2009) Undang Undang tentang Kepariwisataan, UU No. 10 Tahun 2009. Jakarta. Direktorat Jenderal Hukum dan HAM

Salleh, N. H. M., Shukor, M. S., Othman, R., Samsudin, M., \& Idris, S. H. M. (2016). Factors of local community participation in tourism-related business: Case of Langkawi Island. International Journal of Social Science and Humanity, 6(8), 565571.

Sugiono. P. Dr. (2012). Metode Penelitian kombinasi (Mixed Methods). Bandung; Alfabeta
Available at http://jurnal.unimed.ac.id/2012/index.php/geo e-ISSN: 2549-7057 | p-ISSN: 2085-8167

Suharsimi, A. (2006). Prosedur penelitian suatu pendekatan praktik. Jakarta: Rineka Cipta, 120-123.

Vygotsky, L. S. (1978). Mind in Society: The Development of Higher Psychological Processes. Cambridge. MA Harvard University Press. 